\title{
Calculation of threshold Olsen $P$ values for fertilizer response from soil properties
}

\author{
Ramiro Recena ${ }^{1}$ - Isabel Díaz ${ }^{2} \cdot$ María Carmen del Campillo ${ }^{3} \cdot$ José $_{\text {Torrent }}{ }^{3}$. \\ Antonio Delgado ${ }^{1}$
}

Accepted: 28 July 2016 / Published online: 23 September 2016

(C) INRA and Springer-Verlag France 2016

\begin{abstract}
Phosphorus (P), a non-renewable resource, needs to be used more efficiently in agriculture. This requires using soil $\mathrm{P}$ tests. However, the $\mathrm{P}$ test threshold values for fertilizer response depend on many soil properties, some of which may be useful to estimate these threshold values, others not. Therefore, we searched here which soil properties are useful to estimate $\mathrm{P}$ threshold values. We calculated the threshold values for Olsen $\mathrm{P}$ and $0.01 \mathrm{M} \mathrm{CaCl}_{2}$ extractable $\mathrm{P}$ of 18 representative agricultural soils of the Mediterranean region of Spain. For that, we performed a $\mathrm{P}$ starvation experiment in which wheat and sunflower were alternatively pot-cropped. Results show that Olsen P threshold values are negatively correlated to $\mathrm{P}$ buffer capacity ( $r$ of -0.74 , P lower than $0.001)$, clay content $(-0.82,0.001), \mathrm{pH}(-0.76,0.001)$, and $\mathrm{Fe}$ oxide content $(-0.55,0.05)$. Multiple regression models involving clay, $\mathrm{pH}$ or soil organic $\mathrm{C}$, and phosphatase activity or organic hydrolysable $\mathrm{P}$ accounted for as much as $87 \%$ of the variance in calculated Olsen $\mathrm{P}$ threshold values. In particular, there is a major effect of organic P on Olsen P threshold values. Single models based on routinely measured soil properties such as clay content and $\mathrm{pH}$ made accurate predictions of Olsen $\mathrm{P}$ threshold values with $r^{2}$ of 0.81 and $\mathrm{P}$ lower than 0.001 .
\end{abstract}

Antonio Delgado

adelgado@us.es

1 Departamento de Ciencias Agroforestales, ETSIA, Universidad de Sevilla, Ctra. Utrera km 1, 41013 Sevilla, Spain

2 Departamento de Mecánica de Fluidos e Ingeniería Aeroespacial, ETSIA, Universidad de Sevilla, Ctra. Utrera km 1, 41013 Sevilla, Spain

3 Departamento de Agronomía, Universidad de Córdoba, Edificio C4, Campus de Rabanales, 14071 Córdoba, Spain
Keywords Olsen P · Availability index · Threshold values · Buffer capacity · Organic P

\section{Introduction}

Agriculture depends on the use of phosphorus (P) fertilizers obtained from phosphate rock, which is a non-renewable and strategic resource (Keyzer 2010; Van Vuuren et al. 2010). The demand of $P$ fertilizers is expected to grow as the logical result of the growing food needs of an increasing population, whereas the production of PR is expected to peak in the next decades (Schröder et al. 2011; Ryan et al. 2012). Expected future P scarcity is thus emerging as a global challenge for humankind (Cordell and Neset 2014). In addition, the use of P in agriculture is globally very inefficient, in such a way that only $15 \%$ of $\mathrm{P}$ applied to agricultural soil goes into the food chain (Cordell et al. 2009; Withers et al. 2014).

The former considerations point to the need of a more efficient and sustainable use of $P$ in agriculture. In particular, fertilization schemes should rely, among other factors, on accurate distinction of P-responsive sites (Recena et al. 2015) in order to concentrate this resource on soils in which the highest return of $\mathrm{P}$ fertilization is to be expected. This distinction is usually assessed with the use of an "available $\mathrm{P}$ test" or a "soil $\mathrm{P}$ test" that is correlated with plant $\mathrm{P}$ uptake. There is not a universal soil $\mathrm{P}$ test valid for very different soils, and only for Europe, 16 soil $\mathrm{P}$ tests have been proposed (Neyroud and Lischer 2003; Delgado and Scalenghe 2008). Commonly used soil $\mathrm{P}$ tests are based on extraction with a chemical reagent, as is the case for worldwide used Olsen P test (Olsen et al. 1954). The key issue for their practical use is the definition of threshold values below which yield response to fertilizer application can be expected (Delgado and Scalenghe 2008; Tang et al. 
2009). However, although soil $P$ tests are deemed to be useful for assessing $P$ fertilizer needs, they can be inaccurate because the definition of their threshold values is not always precise. In fact, actual threshold values for a given test can range widely among those soils for which its use is recommended, e.g., for Olsen P (Delgado et al. 2010; Sánchez-Alcalá et al. 2015). Thus, Olsen P is not always well related to plant P uptake (Delgado and Torrent 1997; Kulhánek et al. 2007; Tandy et al. 2011). In soils with very similar properties, Delgado et al. (2010) observed a wide range in threshold values for Olsen $\mathrm{P}$, which clearly depended on the soil $\mathrm{P}$ buffer capacity. Sánchez-Alcalá et al. (2014) reported that the threshold values of Olsen P were affected by properties related to the $\mathrm{P}$ sorption capacity of the soil such as carbonate and Fe oxides contents. These threshold values were estimated considering that plants can absorb sufficient $\mathrm{P}$ above a given $\mathrm{P}$ concentration in solution. However, recent studies have revealed that $\mathrm{P}$ concentration in soil solution for a sufficient $\mathrm{P}$ supply may differ from one soil to another (Sánchez-Alcalá et al. 2015). There is not much information on soil properties controlling this threshold $\mathrm{P}$ concentration in solution. In other plant growth experiments, carbonate content and $\mathrm{pH}$ were the soil properties affecting Olsen $\mathrm{P}$ threshold values (Sánchez-Alcalá et al. 2015). Recena et al. (2015) demonstrated that the Olsen $\mathrm{P}$ predictive value for plant $\mathrm{P}$ uptake is affected not only by those soil properties influencing the equilibrium between inorganic phosphate in solution and that in solid phase but also by factors related to organic $\mathrm{P}$ dynamics. However, they did not provide evidence of how threshold values for Olsen P were affected by all these soil properties. In spite of all these contributions, there is not a whole view of all potential soil factors affecting threshold values for a given soil $\mathrm{P}$ test. It can be hypothesized that there is a need of more precise methods to estimate Presponsive sites. One possibility is the development of tests based on more complex P extraction methods such as those using resins (Delgado et al. 2010) or diffusive gradients thin films (Tandy et al. 2011; Santner et al. 2015), which are more sensitive to soil P buffer capacity. Another option is the development of single models that are based on traditional soil $\mathrm{P}$ tests such as Olsen $\mathrm{P}$ in combination with soil properties related to the dynamics of soil P. This would mean that threshold values could be accurately estimated on the basis of routinely determined soil properties. These models should rely on a deeper knowledge on those soil properties affecting the relationship between plant $\mathrm{P}$ uptake and chemically extractable soil P. In this regard, the objectives of the present study were as follows: (i) identification of soil properties affecting threshold Olsen $\mathrm{P}$ values for fertilizer response in a set of representative Mediterranean soils where this test is usually recommended and (ii) to develop simple models based on routinely determined soil properties to estimate accurate threshold values for use of Olsen P as soil P test in these soils.

\section{Materials and methods}

\subsection{Soils}

The set of soils used in this study was the same one as used by Recena et al. (2015), with one additional soil included (18 soils in total). The soils were classed as Mollisols, Entisols, Inceptisols, Alfisols, and Vertisols according to soil taxonomy (Soil Survey Staff 2010). The agricultural use of these soils was detailed in Recena et al. (2015), and the additional soil considered was used for the typical biannual rain-fed crop rotation in Spain, i.e., wheat-sunflower. The main properties of the $0-20-\mathrm{cm}$ soil layer, from which samples were taken, are described in Table 1.

Methods for soil sampling, processing, analysis of basic properties, study of $\mathrm{P}$ and $\mathrm{Fe}$ forms, and $\mathrm{P}$ sorption capacity from $\mathrm{P}$ sorption isotherms are described in Recena et al. (2015). Iron forms included citrate-ascorbate extractable $\mathrm{Fe}$ $\left(\mathrm{Fe}_{\mathrm{ca}}\right)$, mainly related to poorly crystalline $\mathrm{Fe}$ oxides, and citrate-bicarbonate-dithionite extractable $\mathrm{Fe}\left(\mathrm{Fe}_{\mathrm{d}}\right)$, mainly related to crystalline Fe oxides. In addition, the concentration of phytase hydrolysable $\mathrm{P}$ in the alkali $(\mathrm{NaOH})$ and citratebicarbonate extracts of the sequential fractionation scheme described by Recena et al. (2015) to study P forms was also determined. These extracts in the sequential fractionation scheme are supposed to contain inorganic and organic P mostly adsorbed or precipitated as soluble metal phosphates (Saavedra et al. 2007). The phytase hydrolysable $P$ was estimated as the increase in molybdate reactive $\mathrm{P}$ (Murphy and Riley 1962) after $30 \mathrm{~min}$ of incubation of the extract with phytase (Bio-Feed phytase L, Novozimes, Bagsvaerd, Denmark) at $37^{\circ} \mathrm{C}$. To this end, the enzyme was added to the soil extract in $0.2 \mathrm{ml}$ of buffer solution prepared with $0.4 \mathrm{M} \mathrm{C}_{2} \mathrm{H}_{4} \mathrm{O}_{2}$ and $10 \mathrm{mM}$ ethylenediaminetetraacetic acid at $\mathrm{pH} 5.5$ to a final activity of $10 \mathrm{nKat} \mathrm{ml}^{-1}$ and the reaction was stopped by adding $15 \%$ trichloroacetic acid.

Phosphorus concentration in $0.01 \mathrm{M} \mathrm{CaCl}_{2}$ extracts $\left(\mathrm{P}_{\mathrm{CaC1} 2}\right)$ was used as a proxy for the concentration of $\mathrm{P}$ in the soil solution. This extraction was performed in duplicate and at a soil:extractant ratio of 1:10 using $2 \mathrm{~g}$ of soil in $20 \mathrm{ml}$ of extractant in polyethylene falcon tubes that were end-over-end shaken at $2.5 \mathrm{~s}^{-1}$ for $30 \mathrm{~min}$. The extract was centrifuged at $1000 \mathrm{~g}$ for $10 \mathrm{~min}$, and then a portion of $2 \mathrm{ml}$ centrifuged in Eppendorf tubes at 19,000g to remove soil particles with a diameter $>0.05 \mu \mathrm{m}$ (Sánchez-Alcalá et al. 2015). In the remaining solution, molybdate reactive $P$ was determined according to Murphy and Riley (1962). Olsen $\mathrm{P}$ was determined as the molybdate reactive $\mathrm{P}$ in bicarbonate extracts (Olsen et al. 1954). 
As described by Recena et al. (2015), from a collection of soil sites in which the individual samples ranged widely in Olsen P, those soil samples with the two extreme Olsen P values were selected from each site and named "low-P" and "high-P" samples according to their P status. The high-P and low-P samples were examined in order to check that they differed by less than $5 \%$ in the main soil properties. For the experiment described below, soil was ground to $<6 \mathrm{~mm}$. Olsen $\mathrm{P}$ levels in high-P samples were all well above threshold values for fertilizer response according to the current stage of knowledge, even in samples with the lowest values $\left(9 \mathrm{mg} \mathrm{kg}^{-1}\right)$ which were samples with a very high P buffer capacity and thus with expected threshold values below $5 \mathrm{mg} \mathrm{kg}^{-1}$ (Delgado et al. 2010). For most low-P samples, Olsen $\mathrm{P}$ was assumed to be close to threshold values (data not shown; means and range in Recena et al. 2015).

\subsection{Experimental setup}

An experiment intended to deplete soil $\mathrm{P}$ was conducted in a growth chamber (Fig. 1) where durum wheat and sunflower were grown until anthesis twice, whereby simulating a typical rain-fed crop rotation, for both high-P and low-P samples. Thus, for each type of sample of each soil, four successive crops were grown. Polystyrene pots $(5.5-\mathrm{cm}$ diameter, $15-\mathrm{cm}$ high) filled with $300 \mathrm{~g}$ of soil were used. Seeds were pregerminated on a moistened Petri plate for 14 days and, after that, germinated in trays with perlite as substrate and irrigated with deionized water. After 16 days, seedlings were transplanted. For each soil and sample, the number of pots per depletion stage decreased from five in the first stage to two in the last one because $300 \mathrm{~g}$ were removed after each stage for further laboratory analysis. After transplanting, pots were watered daily with $20 \mathrm{ml}$ of a Hoagland-type nutrient solution without phosphorus at $\mathrm{pH} 6-6.5$, sandwiching between three irrigations and one with the same volume of deionized water to avoid salinization of the soil. Plants were grown with a 14-h photoperiod, a relative humidity of $45 \%$ (day period) and $60 \%$ (night period), and an active photosynthetic radiation of $22 \mathrm{~W} \mathrm{~m}^{-2}$. The composition of the solution applied was the following (all concentrations in $\mathrm{mM} \mathrm{l}^{-1}$ ): $\mathrm{MgSO}_{4}$ (2), $\mathrm{Ca}\left(\mathrm{NO}_{3}\right)_{2}(5), \mathrm{KNO}_{3}(5), \mathrm{KCl}(0.05), \mathrm{Fe}-\mathrm{EDDHA}$ $(0.01), \mathrm{H}_{3} \mathrm{BO}_{3}(0.009), \mathrm{MnCl}_{2}(0.0023), \mathrm{CuSO}_{4}$ (0.0005), $\mathrm{ZnSO}_{4}(0.002)$, and $\mathrm{H}_{2} \mathrm{MoO}_{4}(0.0005)$.

\subsection{Plant and soil analysis after cropping}

After each cropping, plant shoots and roots were carefully separated, washed, and finally dried in a forced air oven until constant weight at $65{ }^{\circ} \mathrm{C}$ for at least $48 \mathrm{~h}$. Root and shoot dry matter was then measured. After each cropping step, soil from all the replications for each soil and type of sample was mixed and processed by drying and grounding 
to $6 \mathrm{~mm} ; 300 \mathrm{~g}$ of soil was withdrawn for chemical analysis and ground to pass a $2-\mathrm{mm}$ sieve. In these samples, molybdate reactive $\mathrm{P}$ in bicarbonate and $0.01 \mathrm{M} \mathrm{CaCl}_{2}$ extracts was determined as described previously.

\subsection{Data analysis}

Data from high- and low-P samples were analyzed as a unique set of data for each soil. Dry matter yield for wheat and sunflower was expressed on a relative basis considering as the maximum yield the average dry matter obtained in high-P samples for wheat and sunflower in their first crop. Because Olsen $P$ values were generally above $12 \mathrm{mg} \mathrm{kg}^{-1}$ before the first sunflower crop (data not shown), and sunflower is very efficient in extracting P (Delgado and Torrent 1997), sunflower dry matter yield was not restricted; only two soils showed lower Olsen P values before sunflower (6 and 9) which were considered non-limiting due to the high $\mathrm{P}$ buffer capacity of the soil (Delgado et al. 2010). Threshold values for Olsen $P$ and $\mathrm{P}_{\mathrm{CaCl} 2}$ were estimated according to the Cate and Nelson method (1971). This method provides threshold values for each $\mathrm{P}$ extraction below which the yield significantly decreased from the maximum relative yield defined for each soil and seems more accurate to define threshold values for soil $\mathrm{P}$ test than other methods such as the linear or quadratic plateau fittings or the Mitscherlich-type equations (Mallarino and Blackmer 1992). The critical level for the Cate-Nelson model was estimated as that value of the soil $\mathrm{P}$ test $\left(\mathrm{P}_{\mathrm{CaCl} 2}\right.$ or Olsen $\mathrm{P})$ that maximized the sum of squares between two populations of soil P test values, i.e., above and below threshold values (Geng et al. 2014), using the ANOVA option of Statgraphics 5.1.

\section{Results and discussion}

The set of soils used in this study ranged widely in properties related to P dynamics (Table 1). Regarding phytase hydrolysable $\mathrm{P}$, this can be assumed to be mainly monoesters which can be potentially hydrolyzed by the action of rhizosphere enzymes and can potentially contribute to $\mathrm{P}$ uptake by plants. On average, amounts of these monoesters adsorbed or precipitated as soluble metal phosphates were not negligible since they were equivalent to half of the bicarbonate extractable inorganic $\mathrm{P}$ in soil (Olsen P, Table 1). As expected, the soil $\mathrm{P}$ buffer capacity was positively correlated to clay content (Shirvani et al. 2005) and the content of Fe related to Fe oxides in soil $\left(\mathrm{Fe}_{\mathrm{ca}}+\mathrm{Fe}_{\mathrm{d}}\right)$. On the contrary, soil P buffer capacity was negatively correlated with the ratio of $\mathrm{Fe}$ in poorly crystalline oxides to that in crystalline oxides $\left(\mathrm{Fe}_{\mathrm{ca}} / \mathrm{Fe}_{\mathrm{d}}\right)$ (Table 2 shows $\mathrm{P}$ buffer capacity at $1 \mathrm{mg}^{-1}$ ). This negative correlation is explained by the usual lower affinity of $\mathrm{P}$ for poorly relative to highly crystalline Fe oxides (Colombo et al. 1994). Iron in Fe oxides and the $\mathrm{Fe}_{\mathrm{ca}} / \mathrm{Fe}_{\mathrm{d}}$ ratio were correlated with clay content (Table 2) thus revealing that oxides are part of the clay fraction but also that the ratio of poorly crystalline to crystalline $\mathrm{Fe}$ oxides increased with decreased clay content in soil. On the other hand, the $\mathrm{Fe}$ in $\mathrm{Fe}$ oxides was negatively correlated with the active calcium carbonate equivalent, evidencing that mineral weathering and subsequent precipitation of oxides during soil genesis is inhibited when soil $\mathrm{pH}$ is buffered by carbonate.

Overall, the Cate-Nelson model provided reasonable estimates of threshold values for both soil P tests: median values for the portion of variance explained was $69 \%$ for Olsen $P$ and $74 \%$ for $\mathrm{P}_{\mathrm{CaCl} 2}$ (Table 1). Threshold values for Olsen $\mathrm{P}$ were in the range usually observed in field experiments (Colomb et al. 2007; Bai et al. 2013) and were similar to those described by Delgado et al. (2010) in pot experiments using a similar amount of soil. Observed threshold values for this soil P test ranged widely between soils (Table 1). Such a degree of variability in threshold values for Olsen P was observed by Delgado et al. (2010) in a group of clay soils with a narrow range of variation in soil properties. Sánchez-Alcalá et al. (2015) also observed a wide range for Olsen $\mathrm{P}$ and $\mathrm{P}_{\mathrm{CaCl}}$ threshold values in a group of soils which, in that case, ranged widely in their properties.

Threshold values for both indices were positively correlated, and for both tests, threshold values were negatively correlated with clay (Table 2). In addition to clay, soil properties with which Olsen $\mathrm{P}$ threshold values were correlated were the following: $\mathrm{pH}, \mathrm{P}$ buffer capacity, and $\mathrm{Fe}$ in $\mathrm{Fe}$ oxides; these correlations being also negative (Table 2). Negative correlation with clay and $\mathrm{Fe}$ in $\mathrm{Fe}$ oxides reveals that threshold values decreased with increased P sorption capacity of the soil. Since clay and $\mathrm{Fe}$ oxide content were positively correlated in the group of soils studied (Table 2), the relative contribution of clay and Fe oxides to the $\mathrm{P}$ dynamics is difficult to assess. For the same $\mathrm{P}$ concentration in solution, $\mathrm{P}$ buffer capacity usually increases with increasing $\mathrm{P}$ sorption capacity. This contributes to explain the correlation of clay and Fe in oxides with soil $\mathrm{P}$ buffer capacity (Table 2), which may explain at least in part the observed negative correlation of threshold values with clay and $\mathrm{Fe}$ oxides.

As reported by Delgado et al. (2010), P buffer capacity seems to account for more variation of the Olsen $\mathrm{P}$ threshold values when it is measured at relatively high $\mathrm{P}$ concentration in solution $\left(1 \mathrm{mg} \mathrm{l}^{-1}\right)$ rather than at low concentration (data not shown). Although the correlation of $\mathrm{pH}$ with $\mathrm{P}$ buffer capacity and clay makes it difficult to extract clear-cut conclusions, the effect of $\mathrm{pH}$ can be also ascribed not only to its influence on soil P dynamics but also by its correlation with other mineralogical properties, such as sorbent surface type, also affecting availability to plants (Delgado and Torrent 1997). Threshold values for Olsen $P$ can be accurately predicted in our soils from multiple regressions involving different soil properties. Clay content, $\mathrm{pH}$, and phosphatase activity 
Table 2 Correlation coefficients between different properties of studied soils: threshold values (TV) of Olsen $\mathrm{P}$ and $\mathrm{P}$ in $0.01 \mathrm{M} \mathrm{CaCl}_{2}$ extracts $\left(\mathrm{P}_{\mathrm{CaCl} 2}\right)$, clay, $\mathrm{pH}$, mean of the phosphatase activity in the four crops in high-P samples, organic $\mathrm{C}$, active $\mathrm{Ca}$ carbonate equivalent (ACCE), $\mathrm{Fe}$ in Fe oxides $(\mathrm{Feca}+\mathrm{Fed})$, ratio of citrate-ascorbate to citrate-bicarbonate- dithionite extractable $\mathrm{Fe}\left(\mathrm{Fe}_{\mathrm{ca}} / \mathrm{Fe}_{\mathrm{d}}\right), \mathrm{P}$ buffer capacity at $1 \mathrm{mg} \mathrm{P}{ }^{-1}$ $\left(\mathrm{PBC}_{1}\right)$, phytase hydrolysable $\mathrm{P}$ in citrate-bicarbonate extracts $\left(\mathrm{CB}_{\mathrm{h}}\right)$, and the sum of phytase hydrolysable $\mathrm{P}$ in $\mathrm{NaOH}$ and citrate-bicarbonate extracts $\left(\mathrm{NaOH}_{\mathrm{h}}+\mathrm{CB}_{\mathrm{h}}\right)$ in high-P samples

\begin{tabular}{|c|c|c|c|c|c|c|c|c|c|c|c|}
\hline & $\mathrm{P}_{\mathrm{CaCl} 2} \mathrm{TV}$ & Clay & $\mathrm{pH}$ & Phosphatase & Organic $\mathrm{C}$ & ACCE & $\mathrm{Feca}+\mathrm{Fed}$ & Feca/Fed & $\mathrm{PBC}_{1}$ & $\mathrm{CB}_{\mathrm{h}}$ & $\mathrm{NaOH}_{\mathrm{h}}+\mathrm{CB}_{\mathrm{h}}$ \\
\hline Olsen P TV & $0.63 * * *$ & $-0.82 * * *$ & $-0.76 * * *$ & $0.26 \mathrm{~ns}$ & $0.11 \mathrm{~ns}$ & $-0.31 \mathrm{~ns}$ & $-0.55^{*}$ & $0.42 \mathrm{~ns}$ & $-0.74 * * *$ & $0.11 \mathrm{~ns}$ & $0.32 \mathrm{~ns}$ \\
\hline $\mathrm{P}_{\mathrm{CaCl} 2} \mathrm{TV}$ & & $-0.80 * * *$ & $-0.61 * *$ & $-0.33 \mathrm{~ns}$ & $-0.18 \mathrm{~ns}$ & $-0.54 *$ & $0.28 \mathrm{~ns}$ & $0.68 * *$ & $-0.67 * *$ & $0.25 \mathrm{~ns}$ & $0.77 * * *$ \\
\hline Clay & & & $-0.60 * *$ & $0.52 *$ & $-0.31 \mathrm{~ns}$ & $-0.44 \mathrm{~ns}$ & $0.52 *$ & $-0.66^{* *}$ & $0.85 * * *$ & $-0.25 \mathrm{~ns}$ & $0.69 * *$ \\
\hline $\mathrm{pH}$ & & & & $0.41 \mathrm{~ns}$ & $0.17 \mathrm{~ns}$ & $0.71 * *$ & $0.19 \mathrm{~ns}$ & $-0.73 * *$ & $0.57 *$ & $0.27 \mathrm{~ns}$ & $0.2 \mathrm{~ns}$ \\
\hline Phosphatase & & & & & $0.39 \mathrm{~ns}$ & $0.28 \mathrm{~ns}$ & $0.23 \mathrm{~ns}$ & $0.29 \mathrm{~ns}$ & $0.52 *$ & $-0.36 \mathrm{~ns}$ & $-0.48^{*}$ \\
\hline Organic $\mathrm{C}$ & & & & & & $-0.14 \mathrm{~ns}$ & $0.1 \mathrm{~ns}$ & $0.12 \mathrm{~ns}$ & $-0.23 \mathrm{~ns}$ & $0.23 \mathrm{~ns}$ & $0.17 \mathrm{~ns}$ \\
\hline ACCE & & & & & & & $-0.59 * *$ & $-0.70 * *$ & $0.34 \mathrm{~ns}$ & $-0.02 \mathrm{~ns}$ & $-0.35 \mathrm{~ns}$ \\
\hline $\mathrm{Feca}+\mathrm{Fed}$ & & & & & & & & $-0.35 \mathrm{~ns}$ & $0.50 *$ & $0.23 \mathrm{~ns}$ & $0.44 \mathrm{~ns}$ \\
\hline Feca/Fed & & & & & & & & & $-0.46^{*}$ & $-0.24 \mathrm{~ns}$ & $0.55^{*}$ \\
\hline $\mathrm{PBC}_{1}$ & & & & & & & & & & $0.13 \mathrm{~ns}$ & $-0.42 \mathrm{~ns}$ \\
\hline $\mathrm{CB}_{\mathrm{h}}$ & & & & & & & & & & & $0.77 * * *$ \\
\hline
\end{tabular}

ns not significant

$* \mathrm{P}<0.05 ; * * \mathrm{P}<0.01 ; * * * \mathrm{P}<0.001$

in the rhizosphere explained near $90 \%$ of variation in Olsen $\mathrm{P}$ threshold values (Fig. 2a). In addition, clay, soil organic carbon, and the phytase hydrolysable $\mathrm{P}$ in the citrate-bicarbonate fraction explained $75 \%$ of variation in threshold values for Olsen $\mathrm{P}$ (Fig. 2b). These relationships reveal that threshold values for this soil $\mathrm{P}$ test was influenced not only by those factors affecting the equilibrium of inorganic phosphate between the solid and liquid phases of soil, such as P buffer capacity, but also by factors related to organic $\mathrm{P}$ dynamics, such as the amount of hydrolysable organic $\mathrm{P}$ or the phosphatase activity in the rhizosphere. Overall, lower threshold values can be expected with increased contents of hydrolysable organic P (Fig. 2b) due to the contribution of the organic $\mathrm{P}$ to plant supply. This contribution is not taken into account in usual soil $\mathrm{P}$ test which are based on the determination of inorganic P (usually molybdate reactive) in soil extracts.

The wide range of $\mathrm{P}_{\mathrm{CaCl} 2}$ threshold values observed supports the contention that the $\mathrm{P}$ concentration in soil solution above which there is a sufficient $\mathrm{P}$ uptake by plants varies widely depending on soil properties, consistent with previous results (Sánchez-Alcalá et al. 2015). These values were affected negatively by active calcium carbonate, and positively by $\mathrm{Fe}_{\mathrm{ca}} / \mathrm{Fe}_{\mathrm{d}}$, and hydrolysable organic $\mathrm{P}$ in $\mathrm{NaOH}$ and citrate-bicarbonate extracts (Table 2; Fig. 3). This reveals the potential contribution of organic $\mathrm{P}$ to $\mathrm{P}$ supply to plants. The effect of the ratio $\mathrm{Fe}_{\mathrm{ca}} / \mathrm{Fe}_{\mathrm{d}}$ on threshold $\mathrm{P}_{\mathrm{CaCl} 2}$ can be explained by the lower affinity of $\mathrm{P}$ for poorly relative to highly crystalline Fe oxides. This implies that a higher $\mathrm{P}$ concentration in solution can be in equilibrium with the

Fig. 1 Pot starvation experiment: a sunflower in growing chamber with b incipient $P$ deficiency symptoms and $\mathbf{c}$ clear deficiency symptoms and $\mathbf{d}$ wheat with $\mathbf{e} \mathrm{P}$ deficiency symptoms

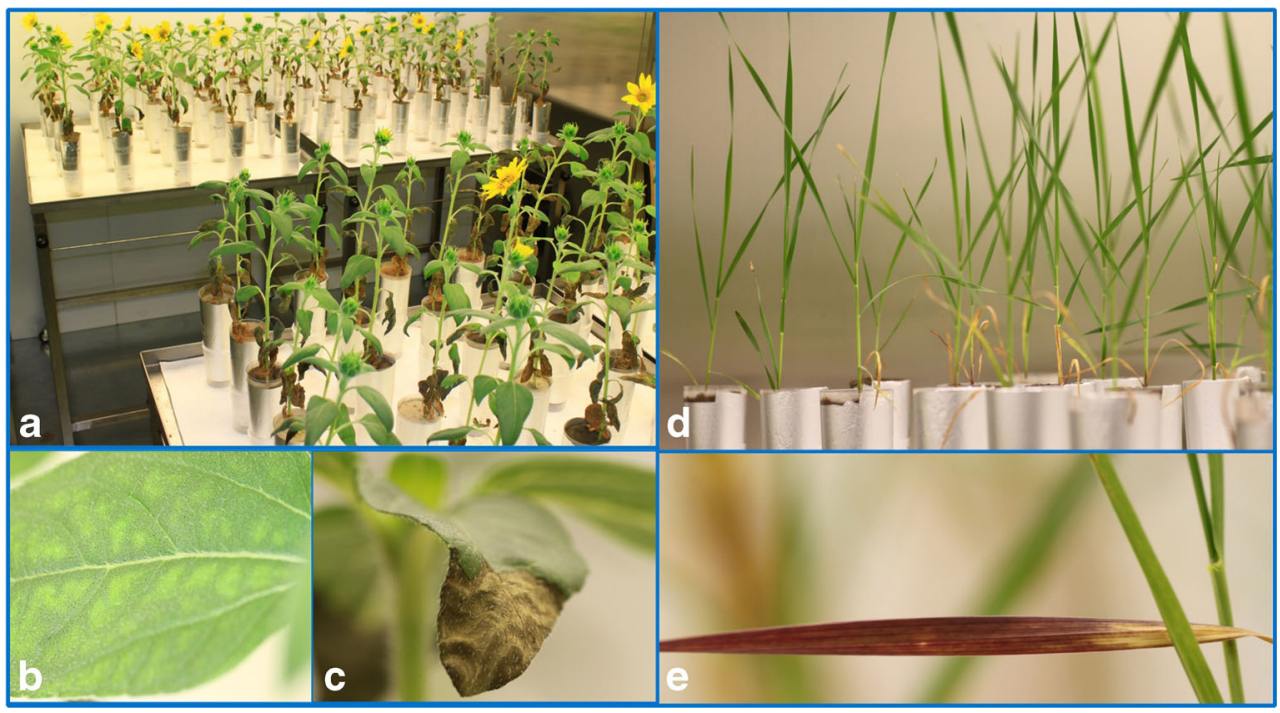




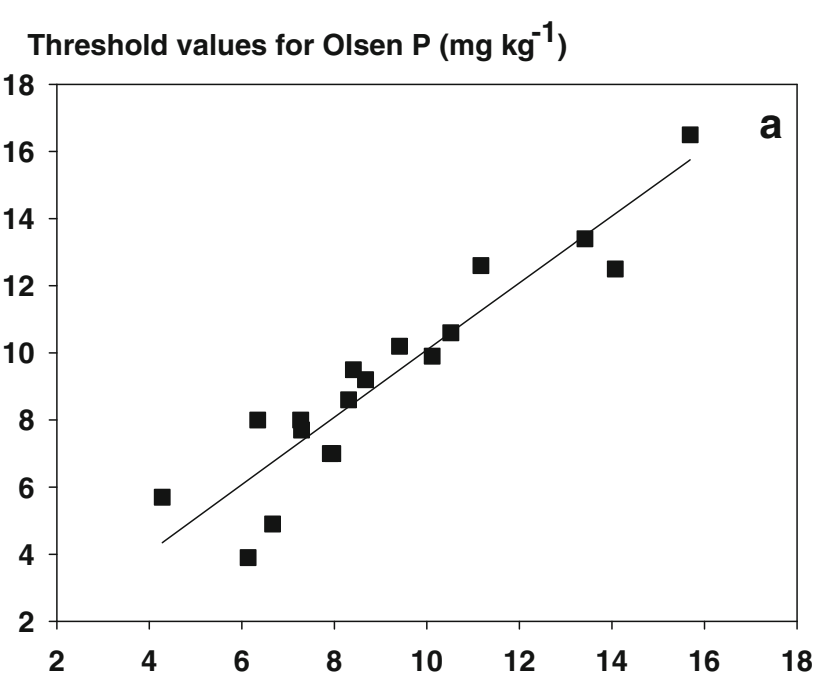

Threshold values for Olsen $\mathrm{P}\left(\mathrm{mg} \mathrm{kg}^{-1}\right)$

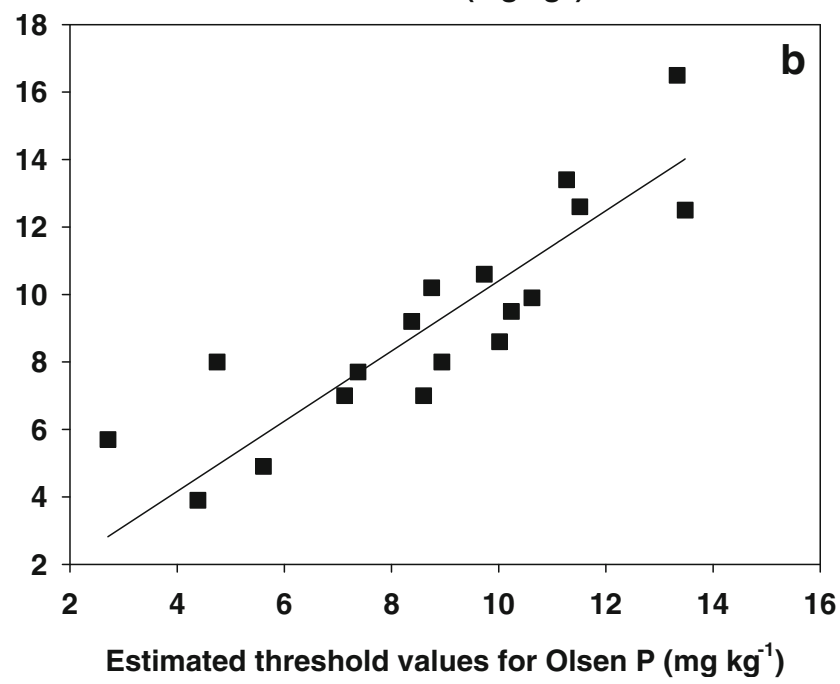

Fig. 2 Estimation threshold Olsen $\mathrm{P}$ values for fertilizer response as a function of a clay, $\mathrm{pH}$, and mean phosphatase activity in the rhizosphere (mean of the four crops in high-P samples); $\mathrm{Y}=32-0.015$ clay -3.26 $\mathrm{pH}+0.05$ phosphatase; $R^{2}=0.87 ; P<0.001$; and coefficients for each explicative variable significant at $P<0.05$ in the least significant case and b clay, soil organic carbon (SOC), and phytase hydrolysable $\mathrm{P}$ in $\mathrm{CB}$ extracts of high-P samples $\left(\mathrm{CB}_{\mathrm{h}}\right) ; \mathrm{Y}=14+2.05 \mathrm{SOC}-0.22$ $\mathrm{CBh}-0.02$ clay; $R^{2}=0.75 ; P<0.001$; and coefficients for each explicative variable significant at $P<0.1$ in the least significant case. Threshold value can be estimated also as a function of clay and $\mathrm{pH} 36$ 0.012 clay-3.02 $\mathrm{pH} ; R^{2}=0.81 ; \mathrm{P}<0.001$; and coefficients for each explicative variable significant at $P<0.01$ in the least significant case and mean absolute error $=1.12$

solid phase at the same amount of sorbed $\mathrm{P}$ with increasing ratio of poorly to highly crystalline Fe oxides. Thus, the type of sorbent surfaces was also a relevant property affecting threshold values.

Phosphorus buffer capacity estimated at $1 \mathrm{mg} \mathrm{l}^{-1}$ seems a crucial property explaining variability in threshold values for Olsen $\mathrm{P}$ and $\mathrm{P}_{\mathrm{CaCl} 2}$. This is in agreement with the current stage of knowledge (Holford 1980; Bolland et al. 1994; Ehlert et al. 2003). Significance of soil P buffer capacity in our long-term
Threshold values for $\mathrm{P}_{\mathrm{CaCl} 2}\left(\mathrm{mg} \mathrm{L}^{-1}\right)$

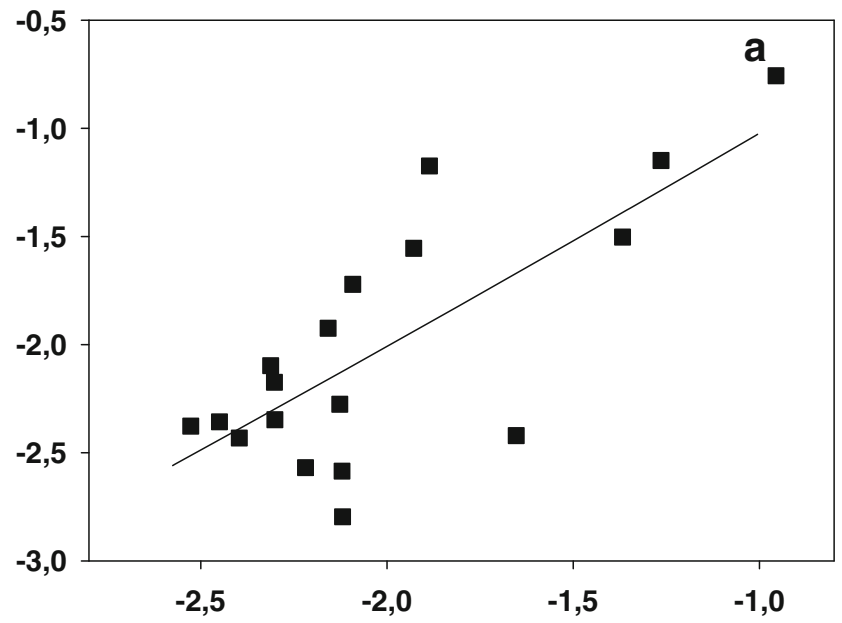

Threshold value for $\mathrm{P}_{\mathrm{CaCl}}\left(\mathrm{mg} \mathrm{L}^{-1}\right)$

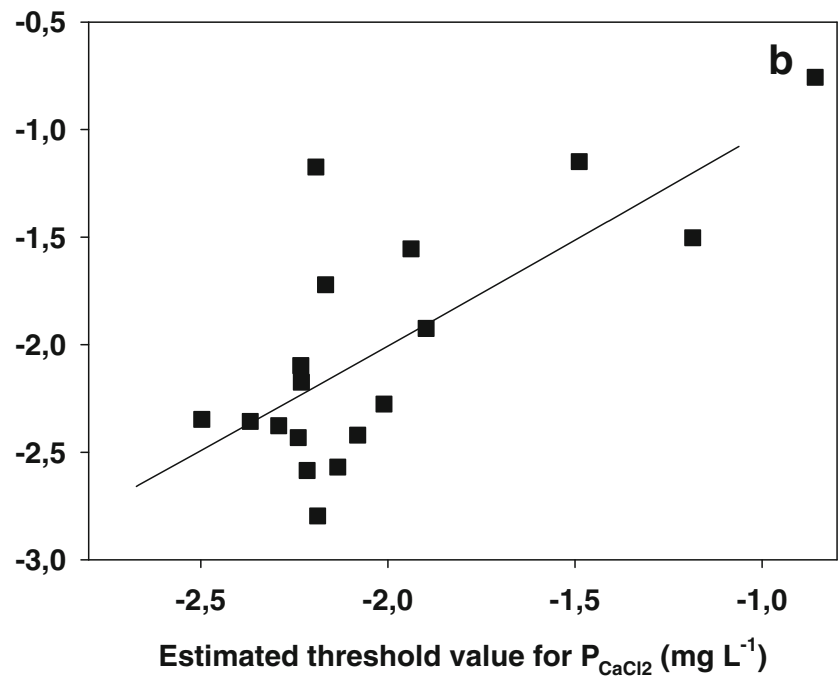

Fig. 3 Estimation of the logarithm of the threshold $\mathrm{P}_{\mathrm{CaCl} 2}$ values for fertilizer response as a function of a clay and the ratio of $\mathrm{Fe}_{\mathrm{ca}}$ to $\mathrm{Fe}_{\mathrm{d}}$, $\mathrm{Y}=-2.02-0.0018$ clay $+2.92 \mathrm{Fe}_{\mathrm{ca}} / \mathrm{Fe}_{\mathrm{d}}, R^{2}=0.57, P<0.001$, and coefficients for each explicative variable significant at $P<0.05$ in both cases and $\mathbf{b} \mathrm{pH}$ and the sum of phytase hydrolysable in $\mathrm{NaOH}$ and $\mathrm{CB}$ extracts, $\mathrm{Y}=2.38-0.62 \mathrm{pH}+0.034\left(\mathrm{NaOH}_{\mathrm{h}}+\mathrm{CB}_{\mathrm{h}}\right), R^{2}=0.54$, $P<0.01$, and coefficients for each explicative variable significant at $P<0.05$ in both cases. Threshold value can be also estimated as a function of clay and active $\mathrm{Ca}$ carbonate equivalent (ACCE), $\mathrm{Y}=-1.13-0.039$ ACCE -0.002 clay. $R^{2}=0.56, P<0.01$, and coefficients for each explicative variable significant at $P<0.05$

depletion experiment for explaining threshold values for Olsen $\mathrm{P}$ was much greater than that observed by Recena et al. (2015) for explaining the ratio of plant P uptake to Olsen $\mathrm{P}$ when $\mathrm{P}$ availability in growing media was scarce. This reveals that $\mathrm{P}$ buffer capacity may be crucial to point to the level of $\mathrm{P}$ in soil at which there is not limitation in $\mathrm{P}$ uptake by plants, but not so relevant in explaining the $\mathrm{P}$ uptake by plants below this level.

Phytase hydrolysable $\mathrm{P}$ in $\mathrm{NaOH}$ and citratebicarbonate extracts was significant in explaining the 
threshold values for both soil P tests when the value considered was that at the beginning of the depletion experiment for the high-P samples (Fig. 2b and Fig. 3b). In addition, phosphatase was significant explaining Olsen $\mathrm{P}$ threshold values when the mean activity for the four depletion steps involving high-P samples was taken into account. This contribution of organic $\mathrm{P}$ to $\mathrm{P}$ supply to plants was previously evidenced by Recena et al. (2015) when the available $\mathrm{P}$ in the growing media was very low in a short-term $\mathrm{P}$ depletion experiment. However, our long-term $\mathrm{P}$ depletion experiment revealed that organic $\mathrm{P}$ also affects the soil $\mathrm{P}$ test value above which plants can take up $\mathrm{P}$ without decrease in yield. The present results reveal that the significant influence of organic P-related factors on threshold values for practical use of Olsen $\mathrm{P}$ as soil $\mathrm{P}$ test in assessing $\mathrm{P}$ fertilization. Moreover, the contribution of organic $\mathrm{P}$ to $\mathrm{P}$ uptake by plants was not restricted to starvation in inorganic available $\mathrm{P}$ as previously observed (Recena et al. 2015); it seemed to be more related to organic $\mathrm{P}$ forms available to enzymatic hydrolysis in the rhizosphere.

Organic carbon in soil also seems to contribute to explain Olsen P threshold values (Fig. 2b). It is well known that dissolved organic matter affects the equilibrium of $\mathrm{P}$ in soil through competition with phosphate for the sorbent surfaces and inhibition of metal phosphate precipitation (Delgado et al. 2002; Saavedra et al. 2007). In addition, increased organic carbon in soils resulting from organic matter addition can promote a decrease in soil P buffer capacity (Sui and Thompson 2000) which also contributes to explain potential effects of soil organic carbon on soil $\mathrm{P}$ test threshold values.

When compared with the current stage of knowledge, the present work provides a more complete view of soil factors affecting the definition of threshold values for Olsen $\mathrm{P}$ and $\mathrm{P}$ in soil solution, as estimated, e.g., by extraction with $0.01 \mathrm{M} \mathrm{CaCl}_{2}$. This was achieved by a deep analysis of the soil properties involved in $\mathrm{P}$ dynamics. From these results, new single models to estimate threshold values based on routinely determined soil properties can be proposed. In the case of Olsen P, a model based on clay and $\mathrm{pH}$ explains $81 \%$ of the variation with an estimated mean absolute error of 1.12 . This in practical terms does not have a relevant economical impact in assessing $\mathrm{P}$ fertilization. Development of these models should be performed, for practical recommendations, at field scale and for different crops because factors affecting root development and the potential contribution of subsurface horizons are relevant for the supply of $\mathrm{P}$ to crops. Our results go beyond the previous ones of Recena et al. (2015), who described the relevant role of properties related to organic $\mathrm{P}$ on $\mathrm{P}$ uptake by plants. In our case, organic P-related properties affect the level of $\mathrm{P}$ in soil above which the supply of $\mathrm{P}$ to the plant is assured, contributing thus to define threshold values for both soil P tests.

\section{Conclusions}

Factors related with the soil $\mathrm{P}$ buffer capacity stand as the most relevant to explain the threshold values for both soil P tests. However, factors related to organic $\mathrm{P}$ dynamics are also influential on the value of soil $\mathrm{P}$ test in soil above which there is a sufficient $P$ supply to plants thus contributing to define threshold values for both soil P tests. In practice, definition of accurate threshold values for Olsen $\mathrm{P}$ in soils of Mediterranean regions should profit from two basic soil properties, namely, clay content and $\mathrm{pH}$. In a simple manner, this could be achieved by defining different ranges of threshold values depending on the clay content and $\mathrm{pH}$ of soil.

Acknowledgments This study was funded by the Spanish Ministry of Science and Innovation and the European Regional Development Fund of the European Union through the National Research, Development and Innovation Program (Plan Nacional I + d + i, AGL2011-29893-CO2-01, and AGL2011-29893-CO2-02) and by the Regional Government of Andalusia (Project AGR 63-85). Mr. Ramiro Recena was a Ph.D. student with a grant from the Regional Government. Fertiberia S.A. and OCA Lebrija collaborated in the collection of soil samples for the present study.

\section{References}

Bai Z, Li H, Yang X, Zhou B, Shi X, Wang B, Li D, Shen J, Chen Q, Qin W, Oenema O, Zhang F (2013) The critical soil P levels for crop yield, soil fertility, and environmental safety in different soil types. Plant Soil 372:27-37. doi:10.1007/s11104-013-1696-y

Bolland MDA, Wilson IR, Allen DG (1994) Effect of P buffer capacity and $\mathrm{P}$ retention index of soils on soil test $\mathrm{P}$, soil test $\mathrm{P}$ calibrations and yield response curvature. Aust J Soil Res 32:503-517. doi:10.1071/SR9940503

Cate RB, Nelson LA (1971) A simple statistical procedure for partitioning soil test correlation data into two classes. Soil Sci Soc Am Proc 35: 658-660. doi:10.2136/sssaj1971.03615995003500040048x

Colombo C, Barrón V, Torrent J (1994) Phosphate adsorption and desorption in relation to morphology and crystal properties of synthetic hematites. Geochim Cosmochim Acta 58:1261-1269. doi:10.1016 /0016-7037(94)90380-8

Colomb B, Debaeke P, Jouany C, Nolot JM (2007) Phosphorus management in low input stockless cropping systems: crop and soil responses to contrasting $P$ regimes in a 36-year experiment in southern France. Eur J Agron 26:154-165. doi:10.1016/j.eja.2006.09.004

Cordell D, Neset TS (2014) Phosphorus vulnerability: a qualitative framework for assessing the vulnerability of national and regional food systems to the multi-dimensional stressors of phosphorus scarcity. Glob Environ Chang 24:108-122. doi:10.1016/j. gloenvcha.2013.11.005

Cordell D, Drangert JO, White S (2009) The story of phosphorus: global food security and food for thought. Glob Environ Chang 19:292305. doi:10.1016/j.gloenvcha.2008.10.009

Delgado A, Torrent J (1997) Phosphate rich soils in the European Union: estimating total plant-available phosphorus. Eur J Agron 6:205-214. doi:10.1016/S1161-0301(96)02048-5

Delgado A, Madrid A, Kasem S, Andreu L, del Campillo MC (2002) Phosphorus fertilizer recovery from calcareous soils amended with humic and fulvic acids. Plant Soil 245:277-286. doi:10.1023 /A:1020445710584 
Delgado A, Scalenghe R (2008) Aspects of phosphorus transfer from soils in Europe. J Plant Nutr Soil Sci 171(4):552-575. doi:10.1002 /jpln.200625052

Delgado A, del Campillo MC, Torrent J (2010) Limitations of the Olsen method to assess available phosphorus in reclaimed marsh soils. Soil Use Manage 26:133-140. doi:10.1111/j.1475-2743.2010.00264.x

Ehlert P, Morel C, Fotyma M, Destain JP (2003) Potential role of phosphate buffering capacity of soils in fertilizer management strategies fitted to environmental goals. J Plant Nutr Soil Sci 166:409-415. doi:10.1002/jpln.200321182

Geng X, Guillard K, Morris TF (2014) Relating turfgrass growth and quality to frequently measured soil nitrate. Crop Sci 54:366-382. doi:10.2135/cropsci2013.03.0145

Holford ICR (1980) Effects of phosphate buffer capacity on critical levels and relationships between soil tests and labile phosphate in wheat growing soils. Aust J Soil Res 18:405-414. doi:10.1071 /SR9800405

Keyzer M (2010) Towards a closed phosphorus cycle. De Economist 158: 411-425. doi:10.1007/s10645-010-9150-5

Kulhánek M, Balík J, Černý J, Nedvědv KB (2007) The influence of different intensities of phosphorus fertilizing on available phosphorus contents in soils and uptake by plants. Plant Soil Environ 53: 382-387

Mallarino AP, Blackmer AM (1992) Comparison of methods for determining critical concentrations of soil test phosphorus for corn. Agron J 84:850-856. doi:10.2134/agronj1992.00021962008400050017x

Murphy J, Riley JP (1962) A modified single solution method for the determination of phosphate in natural waters. Anal Chim Acta 27: 31-36. doi:10.1016/S0003-2670(00)88444-5

Neyroud JA, Lischer P (2003) Do different methods used to estimate soil phosphorus availability across Europe give comparable results? J Plant Nutr Soil Sci 266:422-431. doi:10.1002/jpln.200321152

Olsen SR, Cole CV, Watanabe FS, Dean LA (1954) Estimation of available phosphorus in soils by extraction with sodium bicarbonate. USDA circular 939. US Government Printing Office, Washington DC

Ryan J, Ibrikci H, Delgado A, Torrent J, Sommer R, Rashid A (2012) Significance of phosphorus for agriculture and the environment in the West Asia and North Africa region. Adv Agron 114:91-153. doi:10.1016/B978-0-12-394275-3.00004-3

Recena R, Torrent J, del Campillo MC, Delgado A (2015) Accuracy of Olsen $\mathrm{P}$ to assess plant $\mathrm{P}$ uptake in relation to soil properties and $\mathrm{P}$ forms. Agron Sustain Dev 35:1571-1579. doi:10.1007/s13593-0150332-Z

Saavedra C, Velasco J, Pajuelo P, Perea F, Delgado A (2007) Effects oftillage on phosphorus release potential in a SpanishVertisol. Soil Sci Soc Am J 71:56-63. doi:10.2136/sssaj2006.0162

Sánchez-Alcalá I, del Campillo MC, Barrón V, Torrent J (2014) The Olsen P/solution P relationship as affected by soil properties. Soil Use Manage 30:454-462. doi:10.1111/sum.12141

Sánchez-Alcalá I, Campillo MC, Torrent J (2015) Critical Olsen P and $\mathrm{CaCl}_{2}-\mathrm{P}$ levels related to soil properties: results from micropot experiments. Soil Use Manage. doi:10.1111/sum.12184

Santner J, Mannel M, Burrell LD, Hoefer C, Kreuzeder A, Wenzel WW (2015) Phosphorus uptake by Zea mays L. Is quantitatively predicted by infinite sink extraction of soil P. Plant Soil 386:371-383. doi:10.1007/s11104-014-2271-x

Schröder JJ, Smit AL, Cordell D, Rosemarin A (2011) Improved phosphorus use efficiency in agriculture: a key requirement for its sustainable use. Chemosphere 84:822-831. doi:10.1016/j. chemosphere.2011.01.065

Shirvani M, Shariatmadari H, Kalbasi M (2005) Phosphorus buffering capacity indices as related to soil properties and plant uptake. J. Plant Nutr 28:537-550. doi:10.1081/PLN-200049235

Soil Survey Staff (2010) Keys to soil taxonomy, 11th edn. USDA-Natural Resources Conservation Service, Washington, DC

Sui Y, Thompson ML (2000) Phosphorus sorption, desorption, and buffering capacity in a biosolids-amended mollisol. Soil Sci Soc Am J 64:164-169. doi:10.2136/sssaj2000.641164x

Tandy S, Mundus S, Yngvesson J, de Bang TC, Lombi E, Schjoerring JK, Husted S (2011) The use of DGT for prediction of plant available copper, zinc and phosphorus in agricultural soils. Plant Soil 346: 167-180. doi:10.1007/s11104-011-0806-y

Tang X, Ma Y, Hao X, Li X, Li J, Huang S, Yang X (2009) Determining critical values of soil Olsen-P for maize and winter wheat from longterm experiments in China. Plant Soil 323:143-151. doi:10.1007 /s11104-009-9919-y

Van Vuuren DP, Bouwman AF, Beusen AHW (2010) Phosphorus demand for the 1970-2100 period: a scenario analysis of resource depletion. Glob Environ Chang 20:428-439. doi:10.1016/j. gloenvcha.2010.04.004

Withers PJ, Neal C, Jarvie HP, Doody DG (2014) Agriculture and eutrophication: where do we go from here? Sustainability 6:5853-5875. doi:10.3390/su6095853 